\title{
Connessioni per una didattica multidisciplinare: pensiero e espressività della comunicazione
}

\author{
Carlo Anastasio \\ Emanuela Paternò \\ Rita Valenti
}

Abstract

Il lavoro proposto, sintesi tra insegnamento e ricerca applicata, esplora una forma di connessione tra due ambiti che si differenziano per approccio comunicativo, pur riguardando entrambi la comunicazione delle idee. In dettaglio, l'uno fa riferimento alla comunicazione visiva, espletata in vari ambiti progettuali attraverso la rappresentazione, l'altro utilizza le parole come mezzo espressivo e comunica attraverso il giornale.

Entrambe le aree tematiche, in seguito alla rivoluzione digitale, si sono interrogate sulla necessità di trovare nuovi modi per governare il processo di cambiamento in atto; il linguaggio grafico si è arricchito di strumenti consoni alla trasmissione dei contenuti e i giornali esplorano nuove strade (sia in forma cartacea che digitale) per catturare l'attenzione del lettore.

A partire da queste considerazioni, nell'ambito del corso di Grafica e gestione delle immagini digitali si è sperimentato un approccio multidisciplinare che ha connesso i due ambiti, attivando una didattica di tipo laboratoriale in cui le esperienze creative delle esercitazioni proprie della disciplina sono state riversate nel seminario relativo alla grafica del giornale.

La metodologia didattica per l'apprendimento multidisciplinare ha suscitato la partecipazione attiva degli studenti di due anni di corso; le connessioni e gli interscambi tra i due ambiti tematici si sono rivelate fondamentali e generatrici di un approccio innovativo per le scuole di architettura.

Parole chiave

didattica, grafica, giornale, integrazione dei saperi.
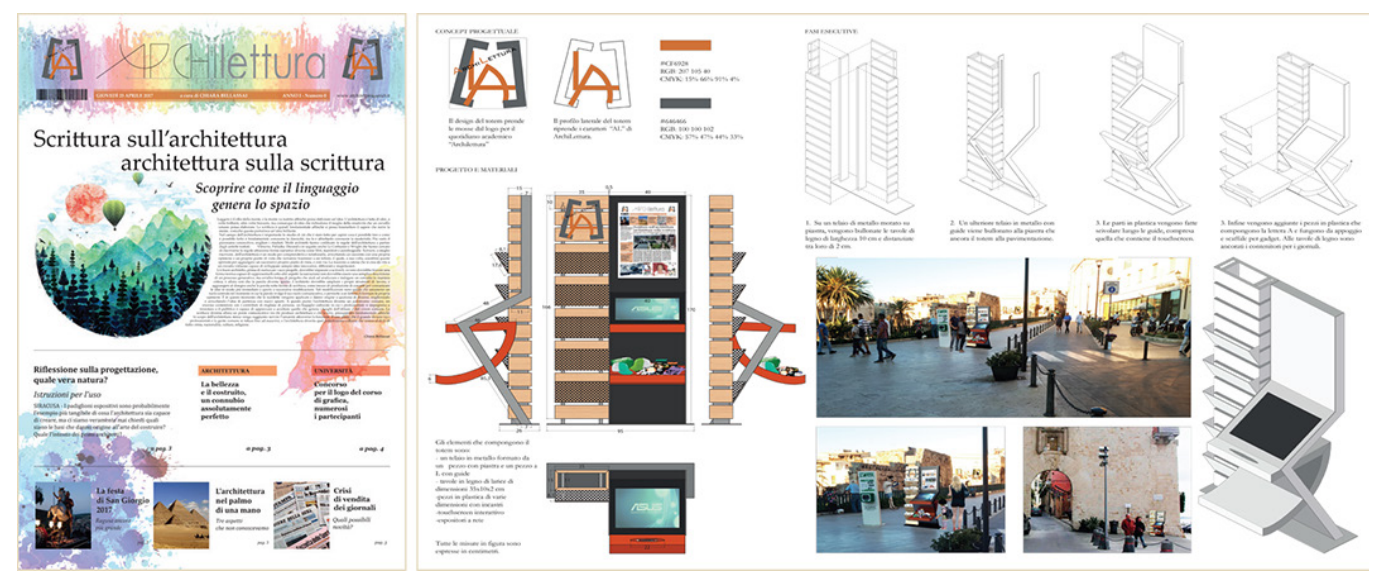


\section{Introduzione: connessioni per la comunicazione del pensiero}

La formazione nelle scuole di architettura assume un ruolo fondamentale specialmente in relazione all'attuale contesto caratterizzato da una rapida evoluzione degli strumenti che, nella fattispecie, comporta la ricerca di metodologie didattiche innovative indirizzate verso l'individuazione di percorsi per la produzione e la diffusione di contenuti adeguati alla contemporaneità [Mulè 20।8].

In ambito disciplinare il disegno, nella sua accezione attuale, per esplicarsi necessita di un supporto che può riferirsi alla tradizione cartacea o alla consolidata prassi digitale, in entrambe le modalità uno dei suoi ruoli precipui è comunicare e dare forma al pensiero durante l'atto creativo. Nell'attività progettuale la comunicazione attraverso il disegno si configura come strumento di espressione per esercitare quella "serie di operazioni fatta di valori oggettivi che diventano strumenti operativi nelle mani di progettisti creativi" [Munari 1981, p. 17].

II dominio della rappresentazione diventa la sorgente di idee e forme il cui lo sbocco non si limita al progetto di architettura e si estende oltre, fino a comprendere ogni forma di espressione visuale [Valenti 2009, p. 31].

II lavoro proposto, sintesi tra insegnamento e ricerca applicata, esplora una forma di connessione tra due ambiti che si differenziano per approccio comunicativo, pur riguardando entrambi la comunicazione delle idee. In dettaglio, l'uno fa riferimento alla comunicazione visiva, espletata in vari ambiti progettuali attraverso la rappresentazione, l'altro utilizza le parole come mezzo espressivo e comunica attraverso il giornale. (figg. I, 2). (R.V.).

\section{Espressività e grafica: una sintesi metodologica multidisciplinare}

Riscontrare legami e connessioni tra le forme di espressione artistica (arti visive in generale) e l'architettura è usuale: molti sono gli esempi nell'architettura contemporanea di architetti che scambiano tra arte e progetto. Peter Eisenman con l'idea di edificio-scultura, Steven Holl con i suoi acquerelli da recente in mostra alla Galleria Antonia Jannone di Milano, Santiago Calatrava con le sue sculture e i suoi acquerelli in mostra al museo Capodimonte
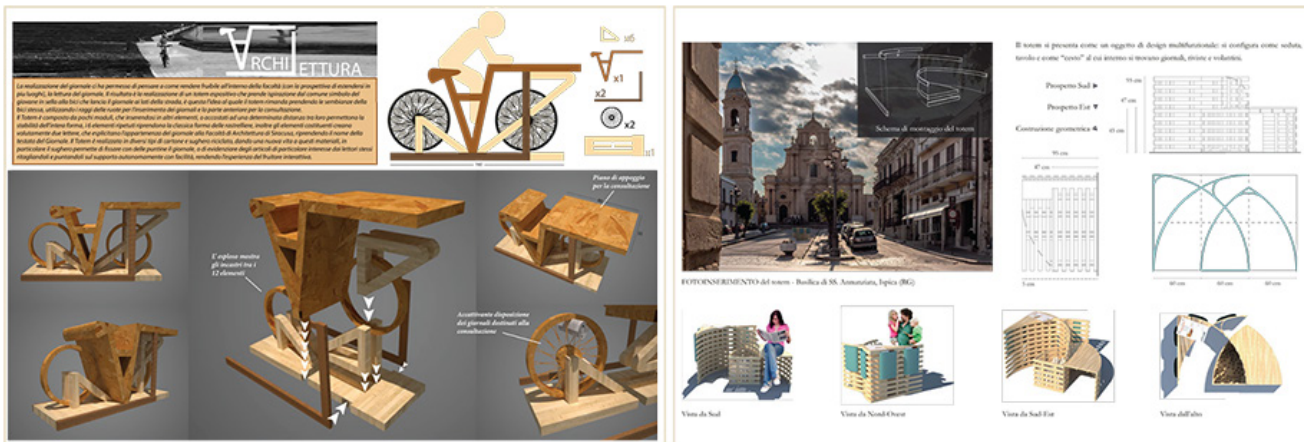

Fig. I. Elaborazioni di totem per l'esposizione e la lettura del giornale (elaborazioni degli studenti del corso
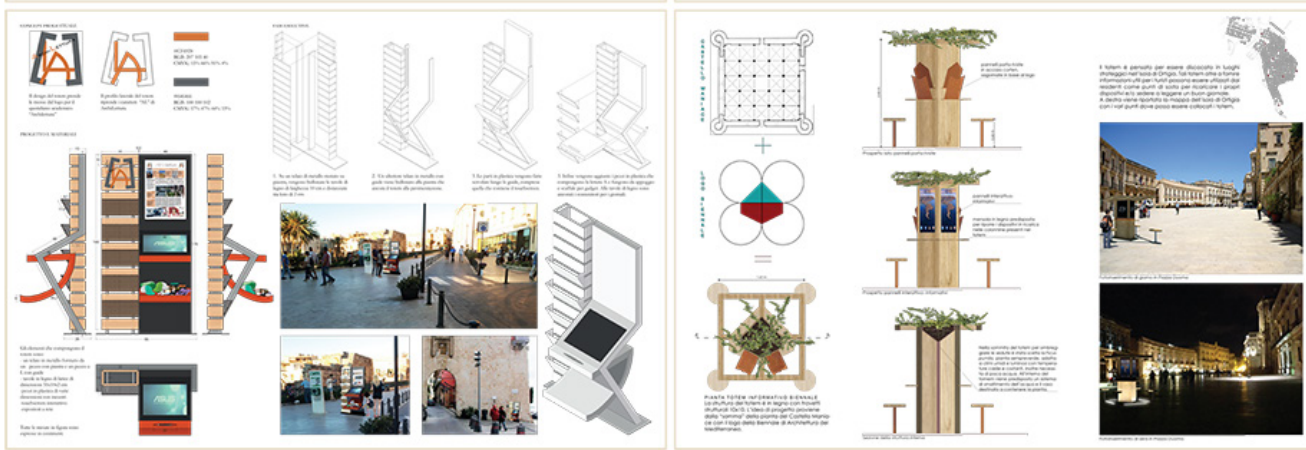
di Napoli, Daniel Libeskind, Zaha Hadid con i suoi disegni e le opere pittoriche, sono solo alcuni riferimenti che coniugano arte e architettura.

Lo scambio sinergico tra il mondo della rappresentazione, coinvolto nella progettazione di adeguate modalità espressive finalizzate alla comunicazione, e il campo del giornale, inteso come ambito preposto alla informazione attraverso la comunicazione scritta, è una connessione insolita per le scuole di architettura.

In realtà, entrambe le aree tematiche si sono interrogate sulla necessità di trovare nuovi modi per governare il processo di cambiamento in atto indotto dall'era digitale; in particolare il linguaggio grafico si è arricchito di strumenti consoni alla trasmissione dei contenuti e i giornali esplorano nuove strade (sia in forma cartacea che digitale) per catturare l'attenzione del lettore.

A partire da queste considerazioni, nell'ambito dei corsi di Grafica e gestione delle immagini digitali, svoltisi tra il 2016 e il 2018 , si è sperimentato un approccio multidisciplinare che ha connesso i due ambiti, attivando una didattica di tipo laboratoriale in cui le esperienze creative delle esercitazioni proprie della disciplina sono state riversate nel seminario relativo alla grafica del giornale (fig. 3).

Al riguardo, si è ridefinito il quadro di azione della didattica che ha messo in campo la collaborazione tra il docente del corso e una figura altamente qualificata di giornalista.

L'intento è stato di convogliare la creatività propria dello studente di architettura in un ambito 'diversamente' progettuale, in modo da arricchire l'esperienza di studio con simulazioni reali proiettate verso l'innovazione.

Si è così attivata una sperimentazione sia nel settore della didattica in aula, sia dal punto di vista progettuale della grafica editoriale. II giornalista ha fornito le conoscenze di base per stimolare un approccio innovativo di configurazione del giornale.

Nella prima fase dell'approccio sperimentale si sono sviluppati linguaggi visivi finalizzati alla rappresentazione morfologica e materica del concept in relazione a scenari variegati, comprensivi di esperienze che hanno consentito agli studenti di confrontarsi con situazioni reali mediante la partecipazione a concorsi di idee.

Nella seconda fase, l'elaborazione della grafica del giornale si è avvalsa delle esperienze precedenti ed è stata proiettata verso l'elaborazione di un giornale innovativo. (R.V.).

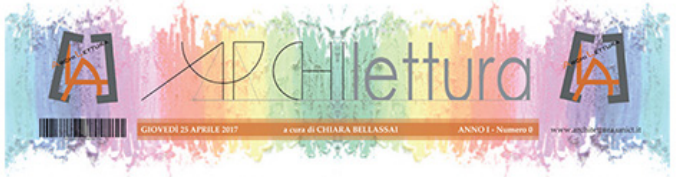

\section{Scrittura sull'architettura} architettura sulla scrittura

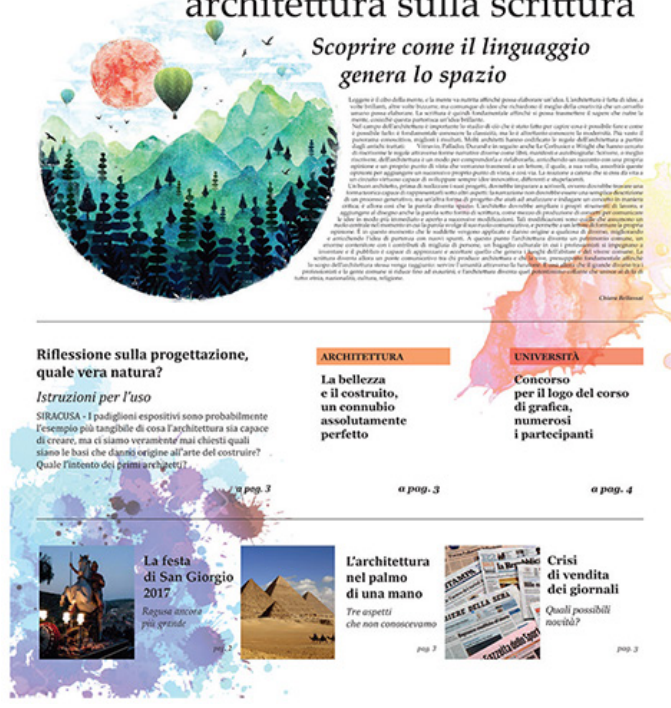

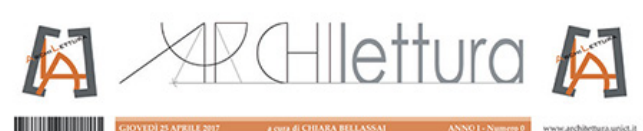

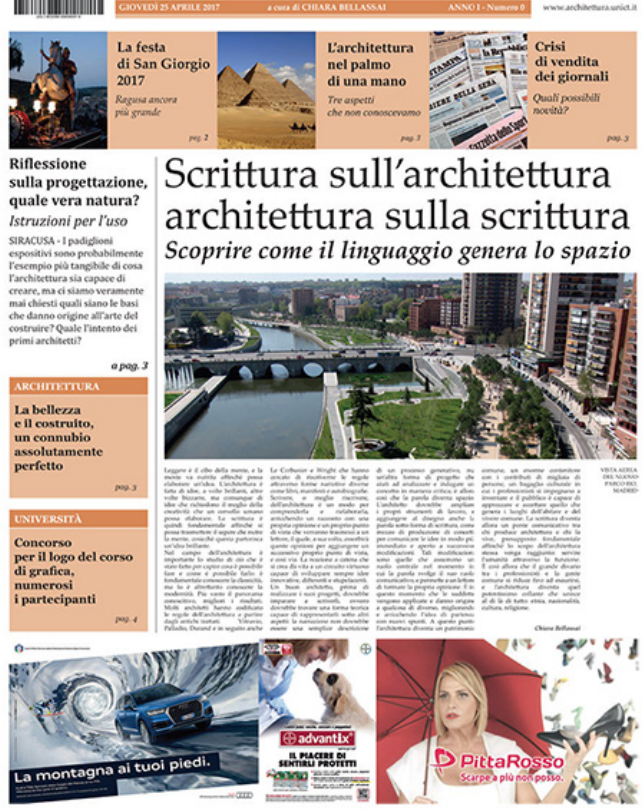




\section{Un concorso di idee}

Nell'era digitale o era dell'informazione in cui viviamo, i 'media' sono sicuramente i protagonisti di un rinnovato sistema di comunicazione rivolto a individuare sistemi sempre più immediati ed efficaci di informazione. II linguaggio utilizzato per compiere tale operazione si basa su immagini, simboli, segni, parole chiave che mirano a presentare in modo chiaro e semplice concetti ampi e/o complessi. Si tratta di una comunicazione 'visiva' in grado di stabilire nuove modalità per informare, educare, persuadere [Munari 1968].

Tale comunicazione attiva un processo di scambio reciproco tra i soggetti coinvolti: da un lato il comunicante ha il compito di trasmettere un messaggio traendo indicazioni dall'esperienza passata e dalla capacità di assegnare significati a simboli e parole; dall'altro lato il ricevente è impegnato in un'attività di comprensione che è influenzata dal contesto culturale e temporale in cui vive. In questa situazione, dunque, l'immagine assume il compito importante di essere veicolo di informazioni per cui definire segni, simboli e parole diventa un'operazione complessa che richiede una progettazione precisa affinché la comprensione del messaggio sia massima e l'equivocità minima. Sulla base di tali considerazioni, risulta indispensabile, nel settore disciplinare della rappresentazione, trasmettere agli studenti l'importanza del disegno e della logica per l'elaborazione di immagini digitali in grado di generare, attraverso gli strumenti opportuni, una grafica dell'informazione.

Per introdurre gli allievi architetti nel mondo della grafica dandogli la possibilità di rapportarsi con la realtà è stato proposto di partecipare a un concorso di idee indetto dall'assessorato del turismo, dello sport e dello spettacolo della regione siciliana per la "creazione di un logo per la promozione turistica della Regione Siciliana". L'obiettivo del concorso era quello di realizzare un simbolo in grado di identificare in maniera immediata e originale la Sicilia nella promozione turistica. Lo stesso doveva accompagnare lo slogan "Sicilia il Paradiso in Terra" garantendo la possibilità di essere utilizzabile su diversi supporti e a diverse grandezze di rappresentazione senza mai perdere la qualità grafica e la chiarezza dei contenuti. Gli studenti, opportunamente guidati dal docente e dal regolamento allegato al bando, doveva-
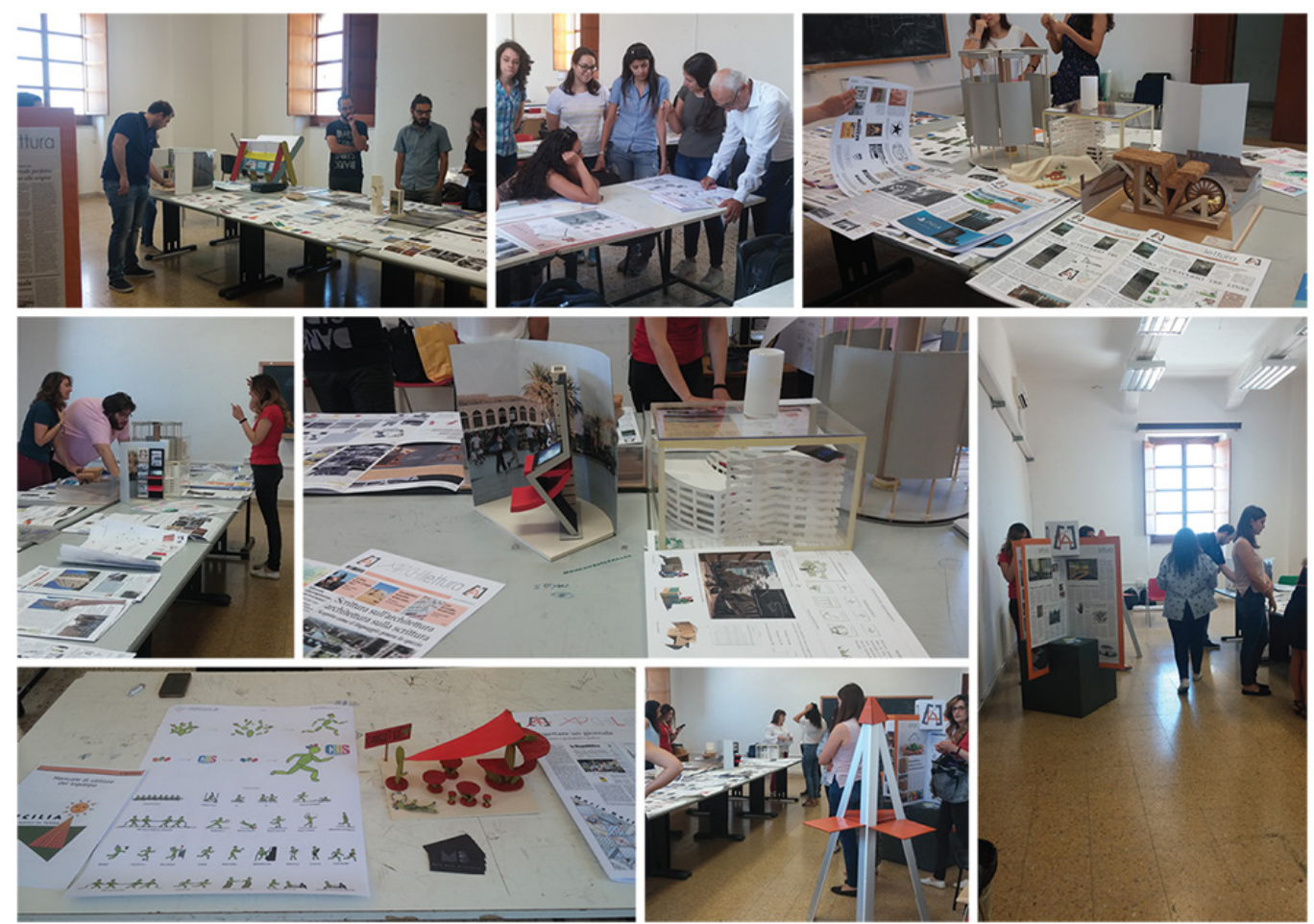
no altresì produrre una breve relazione descrittiva dell'idea progettuale nonché un manuale di utilizzo del logo. La proposta è stata accolta con entusiasmo dai partecipanti che hanno tempestivamente prodotto idee sottoforma di immagini.

Diverse sono state le considerazioni da cui sono partiti i giovani studiosi: alcuni hanno cercato di mettere in evidenza i colori e i profumi della Sicilia sottolineando l'aspetto naturalistico e mettendo in evidenza i prodotti di questa terra; altri invece partendo da alcune considerazioni dello scrittore Guy de Maupassant che definisce la Sicilia un museo di architettura, hanno voluto sottolineare il valore culturale e architettonico della Sicilia; c'è chi invece si è concentrato sui caratteri paesaggistici mettendo in luce gli elementi naturalistici che governano il territorio siciliano come la presenza del vulcano Etna, del mare, del sole che riscalda tutte le stagioni; sono state anche prese in considerazione le tradizioni popolari e culturali riproponendo simboli e oggetti caratterizzanti la Sicilia; molti sono riusciti a rappresentare tutti questi caratteri peculiari in un unico simbolo (fig. 4).

Alla base di questi ragionamenti non potevano mancare le analisi geometriche e l'individuazione di forme e colori. Anche la scelta del font da adottare per lo slogan doveva essere in perfetta armonia con il logo e soprattutto ben visibile e leggibile senza tuttavia sostituirsi al simbolo che doveva in primo luogo suscitare l'interesse e la curiosità del fruitore. Infine, nel manuale di utilizzo doveva essere messa in mostra la possibile applicabilità del logo in diversi contesti come ad esempio nella produzione di gadget, nell'elaborazione di depliant turistici o addirittura nella creazione di siti web o app (fig. 5).

Considerato il riscontro positivo dell'attività didattica proposta si è deciso di effettuare un ulteriore concorso interno convocando una commissione di studiosi e appassionati di grafica e rappresentazione che hanno analizzato gli elaborati proposti e hanno premiato il logo che spiccava per originalità, significato, armonia e applicabilità. (E.P.).

\section{L'architettura dei giornali}

Archilettura è il nome, la testata, dei mini-giornali che per due anni accademici, fra 2016 e 20 I 8, alcune decine di studenti hanno ideato e realizzato per la sezione Grafica dei giornali del corso di Grafica e gestione delle immagini digitali. Architettura e lettura, cioè, unite in un

Fig. 4. Proposte di loghi per la promozione turistica della Regione Siciliana (elaborazioni grafiche degli studenti del corso di Grafica e gestione delle immagini digitali dell'a 2016-2017).
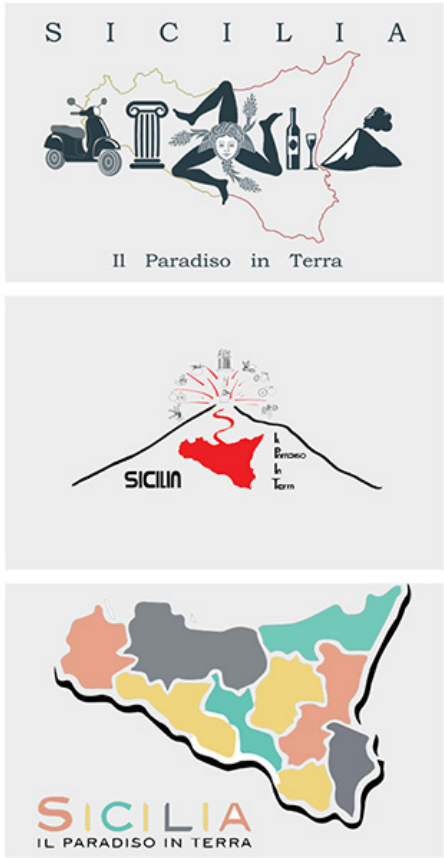
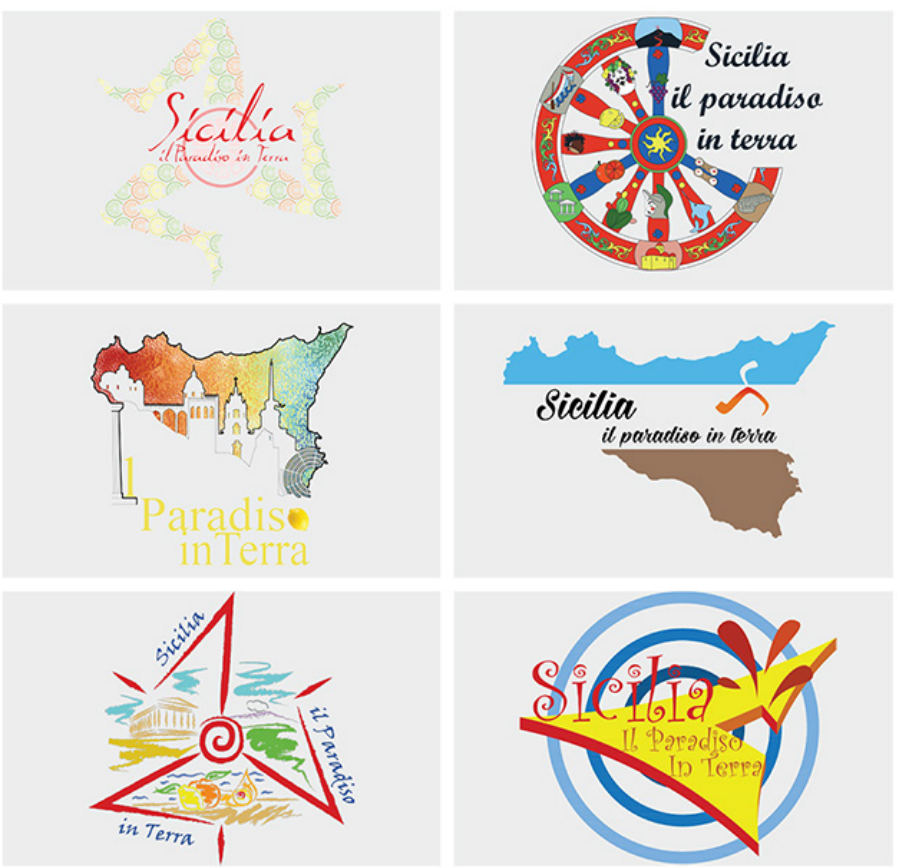
neologismo coniato quasi per divertimento, ma soprattutto fuse insieme in un'esperienza che si è rivelata un crogiuolo di creatività messa in pratica.

L'obiettivo essenziale era fornire la preparazione di base per un eventuale, futuro lavoro nel campo della stampa quotidiana (che, nel contrasto alla gravissima crisi di cui soffre da anni, avrebbe grandi benefici da un ridisegno innovativo di forme e contenuti) [Harrower, Elman 20|3].

Un obiettivo pienamente raggiunto, come si può verificare negli elaborati. Ma l'intera esperienza ha detto qualcosa di più e di inatteso, ossia che la somma degli elementi in gioco è diventata una moltiplicazione.

Sono stati gli interscambi ad avere una funzione generatrice. Dal lato dell'insegnamento, la dialettica e la collaborazione tra il docente titolare del corso e il giornalista incaricato di curarsi di quella sezione. Dal lato dell'apprendimento, il rapporto tra i differenti compiti da portare a termine: ogni mini-giornale infatti è stato costruito non soltanto su disegno degli studenti, ma con articoli e titoli scritti da loro stessi, su temi sia di cronaca sia di commento, e sotto il controllo di revisioni anche di qualità e struttura delle argomentazioni e all'occorrenza di sintassi, perché un articolo deve avere la sua architettura. II lavoro dunque è andato assai oltre la grafica in senso stretto (fig. 6).

Ma cosa c'entra un architetto con il giornalismo e la scrittura, possibilmente buona scrittura? C'era in effetti un motivo tecnico per richiedere lo sforzo aggiuntivo, e a prima vista fuori luogo, dello scrivere: chi disegna la pagina di un giornale dovrebbe conoscere perfettamente gli articoli da pubblicare, perché non soltanto la dimensione ma anche la configurazione e la collocazione degli spazi devono essere correlate agli argomenti e al modo in cui sono trattati [Samara 20 I7; Garcia 2002]; quindi lo studente avrebbe avuto piena cognizione di causa su articoli scritti appunto da lui. Ed è proprio qui che la somma di compiti è diventata una moltiplicazione di idee.

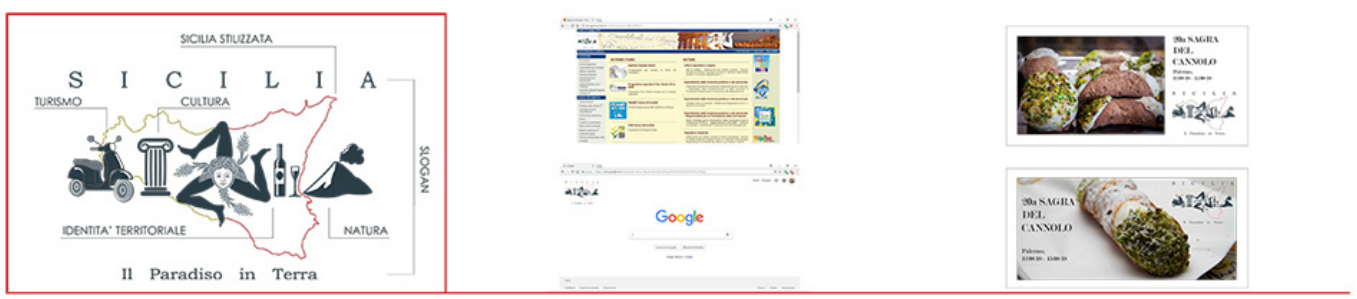

Paradiso in Terra

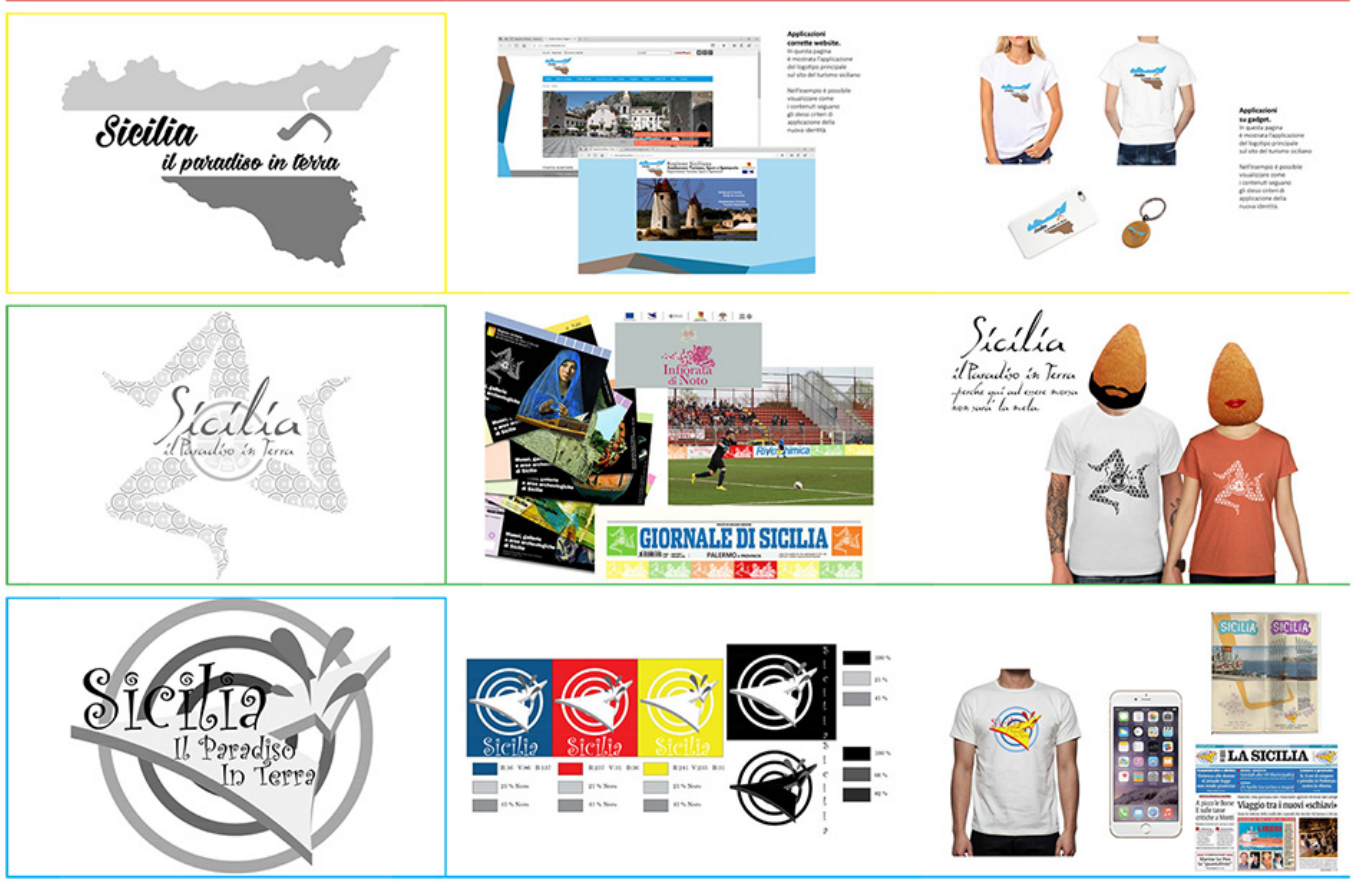


Fig. 6. Archilettura, il giornale progettato dag studenti di architettura (elaborazioni grafiche degli studenti del corso di Grafica e gestione delle immagini digitali dell'a.a. 2016-2017 e 2017-2018).
È avvenuto che alla competenza specifica dell'architetto si è legata una conoscenza collaterale, in questo caso nel campo del giornalismo, e l'effetto complessivo è stato simile al prodotto di associazioni di pensieri: la nascita di nuove intuizioni, di ragionamenti originali. Così, il percorso dello scrivere - con una sorta di feedback - ha portato passo dopo passo a modificare il disegno durante il processo progettuale, e ad arricchirlo. In altre parole, gli studenti hanno creato pagine più funzionali e coinvolgenti - più belle, in definitiva - giusto per il fatto che erano loro stessi gli autori dei testi.

Un esito analogo si è avuto con le inserzioni pubblicitarie. Nel secondo dei due anni accademici, ciascuno studente ha avuto anche la consegna di inventare la pubblicità sul giornale di un suo ipotetico studio professionale, e di metterla in relazione grafica con la parte giornalistica, mantenendo però una netta distinzione. Consegna insolita, nella realtà, dato che nei quotidiani parte pubblicitaria e parte giornalistica o sono mischiate in articoli ambigui - nel senso di propaganda presentata come cronaca - oppure convivono da separate in casa, dentro aree confinanti, e talvolta entrano in conflitto. Gli studenti sono stati invece sollecitati a coniugare il tutto in un disegno organico, in maniera che l'aspetto e i contenuti di ciascuna parte si armonizzassero, senza confondersi, con l'aspetto e i contenuti dell'altra, e insieme si valorizzassero a vicenda. Comprensibilmente, anche questo esercizio ha dato stimolo a concezioni accattivanti (fig. 7).

Alla fine dei conti, giornalismo e marketing sono stati distrazioni per questi giovani aspiranti architetti: ampliamenti non necessari, orizzontali, a fronte dell'approfondimento indispensabile, verticale, delle loro materie specialistiche; e tuttavia la distrazione può avere valore di metodo formativo, specie se conoscenza orizzontale e competenza verticale compongono come trama e ordito un tessuto di capacità. C'è un esempio eccellente. Leonardo da Vinci notoriamente aveva interesse per miriadi di questioni, e seppure il suo disperdersi in diversi rivoli comportava che non completasse alcune opere iniziate, o non ne concretasse altre immaginate, la poliedricità era terreno di coltura per l'inarrivabile eccezionalità dei suoi lavori. Ora, non si sa se dal gruppo degli studenti di Grafica dei giornali verrà fuori qualche genio, ma intanto non sembra che quelle distrazioni gli abbiano fatto male, se non altro perché dalle connessioni fra diversità - la docente, il giornalista, l'architettura, la scrittura, il marketing, il verticale, l'orizzontale - è scaturito un disegno di giornali da cui potrebbero ricavare qualche utile suggerimento non pochi quotidiani oggi sul mercato. (C.A.).
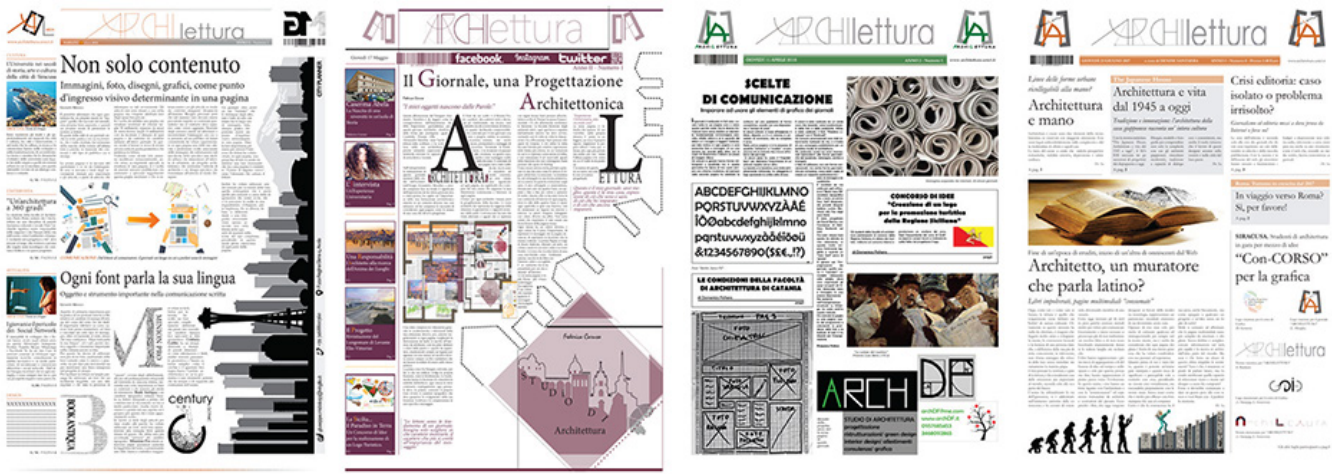

\section{Conclusioni}

L'esperienza dal punto di vista della didattica innovativa ha indotto degli scenari in cui gli studenti hanno mostrato un'alta capacità adattativa nell'affrontare approcci progettuali insoliti. Gli stessi hanno acquisito nuove conoscenze spendibili in ambito professionale, sperimentando percorsi comunicativi completi (grafici e di scrittura) fino ai livelli sia di simulazione (grafica del giornale) sia concreti con la partecipazione al concorso indetto dalla Regione. 
Nel complesso, la metodologia didattica per l'apprendimento multidisciplinare ha suscitato l'entusiasmo e la partecipazione attiva degli studenti dei due anni di corso dal 2016 al 20 I 8; le connessioni e gli interscambi tra i contenuti dei due ambiti tematici si sono rivelate fondamentali e generatrici di un approccio innovativo per le scuole di architettura.

Fig. 7. Giornalismo e pubblicità: esempio di elaborazione grafica (elaborazione grafica di Paolo Florio)

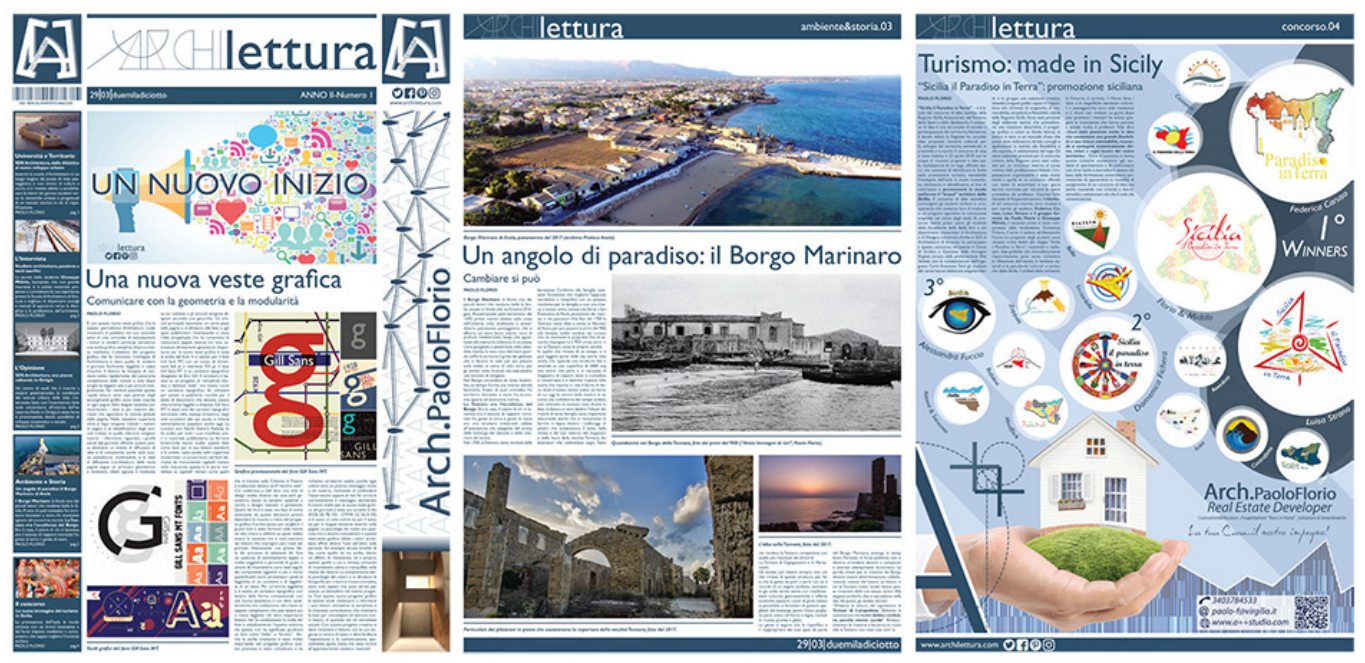

\section{Riferimenti bibliografici}

Garcia Mario (2002). Pure Design79 simple solutions for magazines, books, newspapers, and websites. St. Petersburg, Florida: Miller Media.

HarrowerTim, Elman Julie M. (2013). The Newspaper Designer's Handbook. New York: McGraw-Hill Education.

Mulè Paolina (a cura di). (20 I 8). Didattica generale e didattica disciplinare tra epistemologie e linee programmatiche di intervento. Lecce: Pensa MultiMedia Editore.

Munari Bruno (198I). Da cosa nasce cosa. Bari-Roma: Editori Laterza.

Munari Bruno (1968). Design e comunicazione visiva. Bari-Roma: Editori Laterza.

Samara Timothy (2017). Making and Breaking the Grid. Rockport: Rockport Publishers.

Valenti Rita (2009). I luoghi del disegno tra rappresentazione e concepimento dell'idea. In Voyantes, 2, pp. 30-35.

Autori

Carlo Anastasio, Quotidiano La Sicilia, carlo.anastasio21@gmail.com

Emanuela Paternò, Università degli Studi di Catania, patermanu@hotmail.it

Rita Valenti, Università degli Studi di Catania, r.valenti@unict.it

Per citare questo capitolo: Anastasio Carlo, Paternò Emanuela, Valenti Rita (2020). Connessioni per una didattica multidisciplinare: pensiero e espressività dell comunicazione/Connections for a multidisciplinary teaching approach: thought and expressiveness of communication. In Arena A., Arena M., Brandolino R.G., Colistra D., Ginex G., Mediati D., Nucifora S., Raffa P. (a cura di). Connettere. Un disegno per annodare e tessere. Atti del $42^{\circ}$ Convegno Internazionale dei Docenti delle Discipline della Rappresentazione/Connecting. Drawing for weaving relationships. Proceedings of the 42th International Conference of Representation Disciplines Teachers. Milano: FrancoAngeli, pp. 31 - 46. 


\title{
Connections for a Multidisciplinary Teaching Approach: Thought and Expressiveness of Communication
}

\author{
Carlo Anastasio \\ Emanuela Paternò \\ Rita Valenti
}

Abstract

The proposed study, synthesis of teaching and applied research, explores a type of connection between two fields with different communicative approaches, even if both of them deal with the skill of communicating ideas. Specifically, one refers to visual communication, carried out in different project areas through representation. The other uses words as an expressive medium to communicate through newspapers.

Both areas, after the digital revolution, raised the question of finding new ways to govern the present process of change. In particular, graphics developed new appropriate instruments of content transmission whereas papers are following new routes (both in the printed and digital version) to catch readers' attention.

Taking this into consideration, a multidisciplinary teaching approach was adopted within the course of "Graphics and digital image processing". It was possible to connect the two different fields implementing didactic laboratories whose creative experiences made during specific workshops had an immediate impact on the seminar about the newspaper graphic design.

In conclusion, the multidisciplinary teaching methodology generated great enthusiasm and the active participation of two-year course students. The connections and the exchanges between the contents of the two thematic fields turned out to be successful for an innovative teaching approach in architecture.

Keywords

didactics, graphics, newspaper, integration of knowledge.

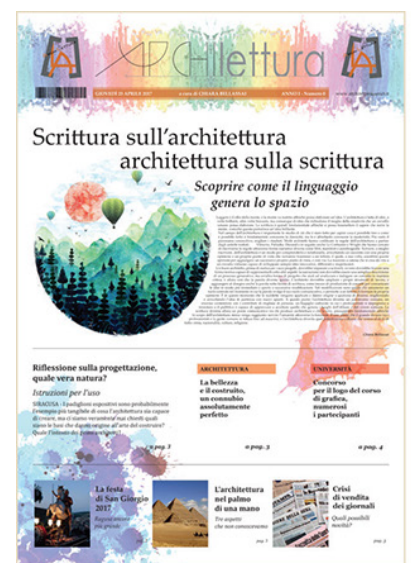

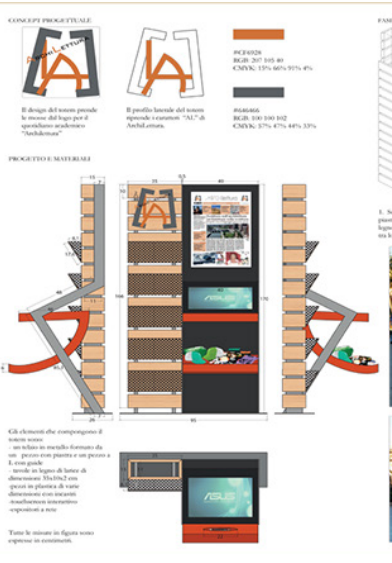

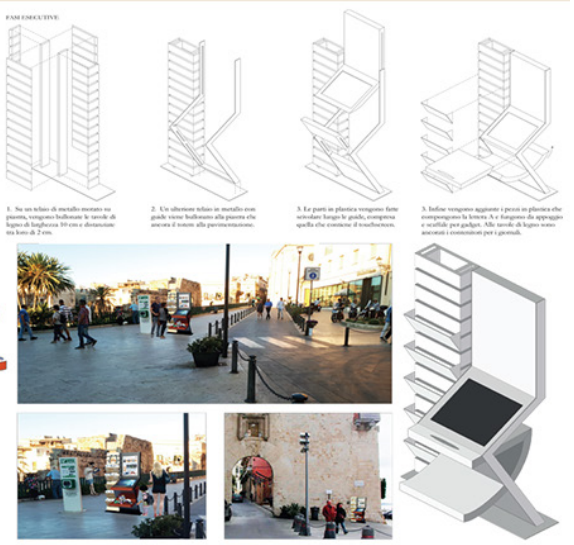

doi.org// 0.3280/oa-548.3 


\section{Introduction: connections with the communication of ideas}

Training has a central role in architecture faculties, especially in relation with the present context characterised by the spread of technological innovation which focuses on the adoption of innovative teaching methodologies directed towards the development of content creation and dissemination, appropriate to the modern world [Mulè 20।8].

In its current standard form, drawing needs a format, on paper or digital, to be processed. In both cases, its main purpose is to communicate and give shape to ideas during creation. In a project, drawing represents an instrument of expression and communication to practice that "series of operations made up of objective values which become active operations in the hands of creative designers" [Munari 1981, p. 17].

Representation, then, becomes the source of ideas and shapes whose natural outcome goes beyond the project itself, including any form of visual expression [Valenti 2009, p. 3 I].

The present study, a synthesis of teaching methodology and applied research, explores the possibility of a connection between two different communicative approaches even if both of them deal with the communication of ideas.

More specifically, one refers to visual communication, performed in different project areas through representation, the other uses words as a means of expression and communicates mostly by newspapers. (figs. I, 2). (R.V.).

\section{Expressiveness and graphics: a multidisciplinary methodological synthesis}

It is common to find connections between different forms of art (visual arts in general) and architecture: in contemporary architecture there are a lot of architects who mix art and project design. Peter Eisenman with his vision of urban sculpture, Steven Holl with his watercolours recently on display at the Galleria Antonia Jannone in Milan, Santiago Calatrava with his sculptures and watercolours on display at the Capodimonte Museum in Naples, Daniel Libeskind, Zaha Hadid with her paintings and drawings, are some famous examples of art and architecture mixed together.
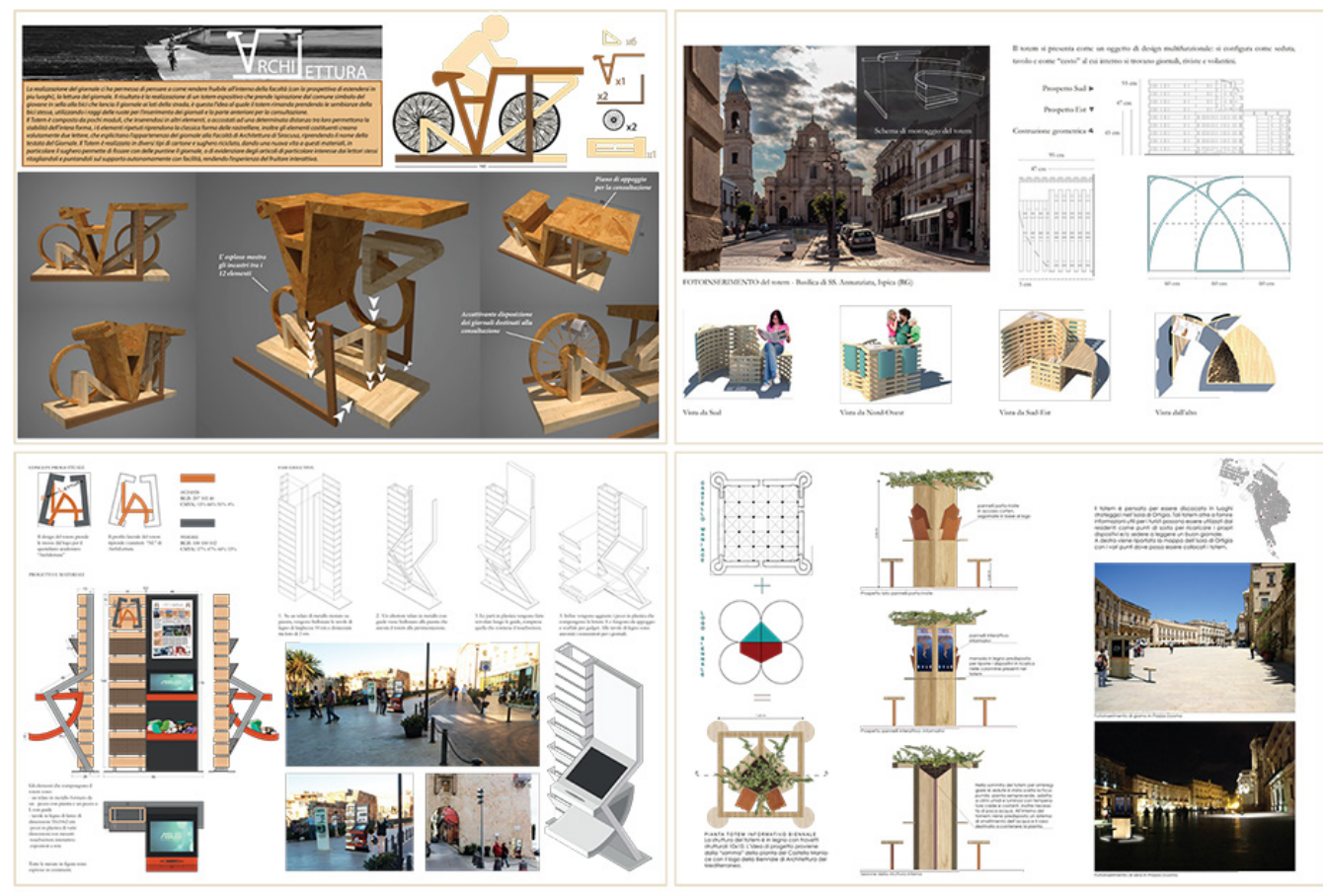
The synergy between representation which involves appropriate methods of expression and journalism which is based on written news reports, is an unusual connection in architecture. Actually, both disciplines feel the need to implement the recent technological innovations. In particular, graphics have adopted appropriate instruments for content transmission and newspapers (both printed or digital) are exploring new ways to attract readers' attention. For these reasons, within the course of Graphics and digital image processing, held in the years 2016 and 2018, a multidisciplinary approach was adopted. The two different fields were interconnected with teaching workshops where the creative experiences of the discipline were transferred to the seminar about newspaper graphics (fig. 3).

Even more, teaching methodology was reconsidered and involved the collaboration between the teacher of the course and a highly qualified journalist.

The purpose was to convey the students' creativity in a 'different' project cycle and to enlarge their study experience with real innovative simulations.

Therefore, an experimentation with a new teaching approach and a new editorial graphic design was carried out. The journalist provided the fundamental knowledge to stimulate innovative approaches to the newspaper layout.

During the first phase of the experimental process, students developed visual languages for the morphological and material concept representation on multiple levels, facilitating real communication through motivation and exchange of ideas.

In the second phase, students selected all the previous experiences and carried out the newspaper graphic design with a completely innovative approach. (R.V.).

\section{A contest of ideas}

The digital era we are living in is characterised by the 'media' which represent a new communication system which tries to identify more and more intuitive and highly performing technologies. The language able to carry out such operations is based on images, symbols, signs, key words which can transfer clearly and simply complex concepts.

Fig. 2. Connections: architecture and writing between tradition and innovation (graphic elaboration by Chiara Bellassai).

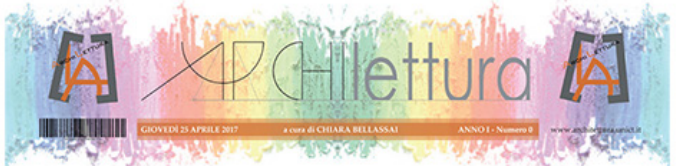

\section{Scrittura sull'architettura} architettura sulla scrittura

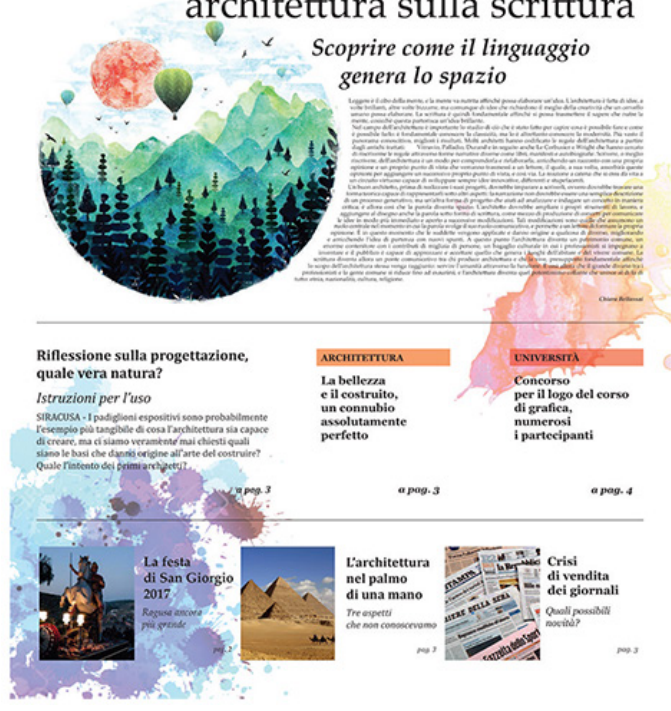

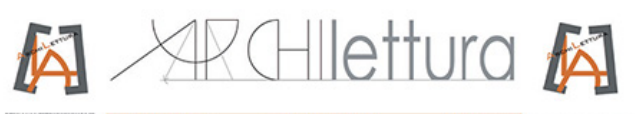
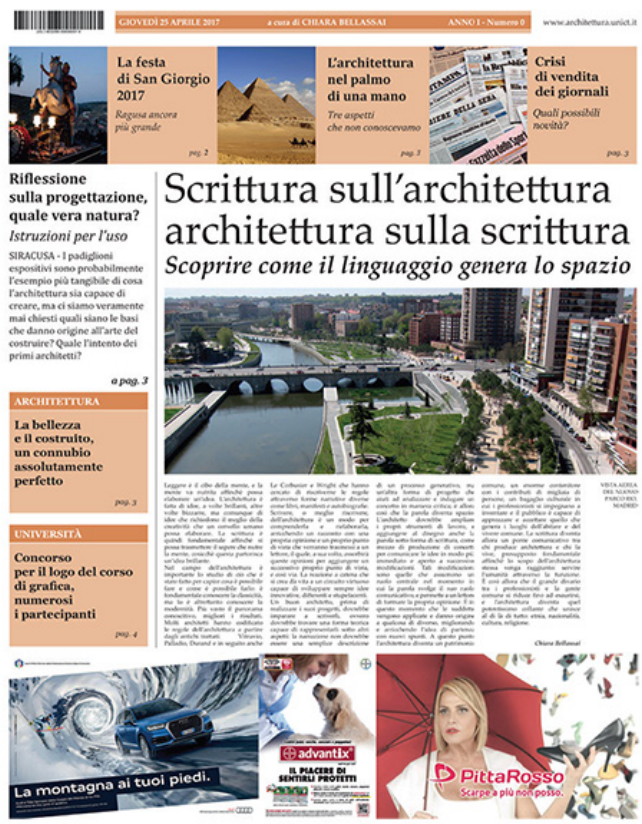
It is, actually, a 'visual' communication which establishes a new modality of information, education and persuasion [Munari 1968].

This type of communication triggers a reciprocal response from the involved users: the sender transmits a message relying on past experiences and on the ability of giving meaning to symbols and words; the receiver is engaged in the interpretation of meaning which is, on its turn, influenced by cultural and social contexts. In this situation, images have a central role in providing information. Therefore, the comprehension of signs, symbols and words becomes a complex operation which needs a precise project plan in order to convey the exact meaning avoiding any source of ambiguity. It is, then, essential for representation to make students understand the importance of drawing and logic to process digital images able to generate infographics, using the appropriate instruments.

In order to introduce students to graphics giving them the possibility of relating to reality they entered a contest of ideas held by the regional authority of tourism, sport and entertainment of Sicily which asked "the creation of a logo for the promotion of tourism in Sicily". The aim of the contest was to develop a symbol able to conceptualize an immediate and original idea of tourism in Sicily. The logo should be accompanied by the slogan "Sicily, an earthly paradise" with the possibility of using it on different devices with different templates maintaining its high graphics quality and clarity.

Students, guided by their teacher, followed the regulation of the contest (call for application) which also required a short description of the project as well as the logo usage guidelines.

The participants showed great enthusiasm and soon their ideas were transformed into images.

Students had different views. Some of them tried to emphasize the colours and aromas of Sicily focusing on its natural aspects and products. Others, quoting the French writer Guy de Maupassant who described Sicily as an open-air museum, emphasized the cultural and architectural value of Sicily. Some students concentrated their efforts on landscape, highlighting the natural elements which characterize Sicily: the volcano Etna, the sea, the sun
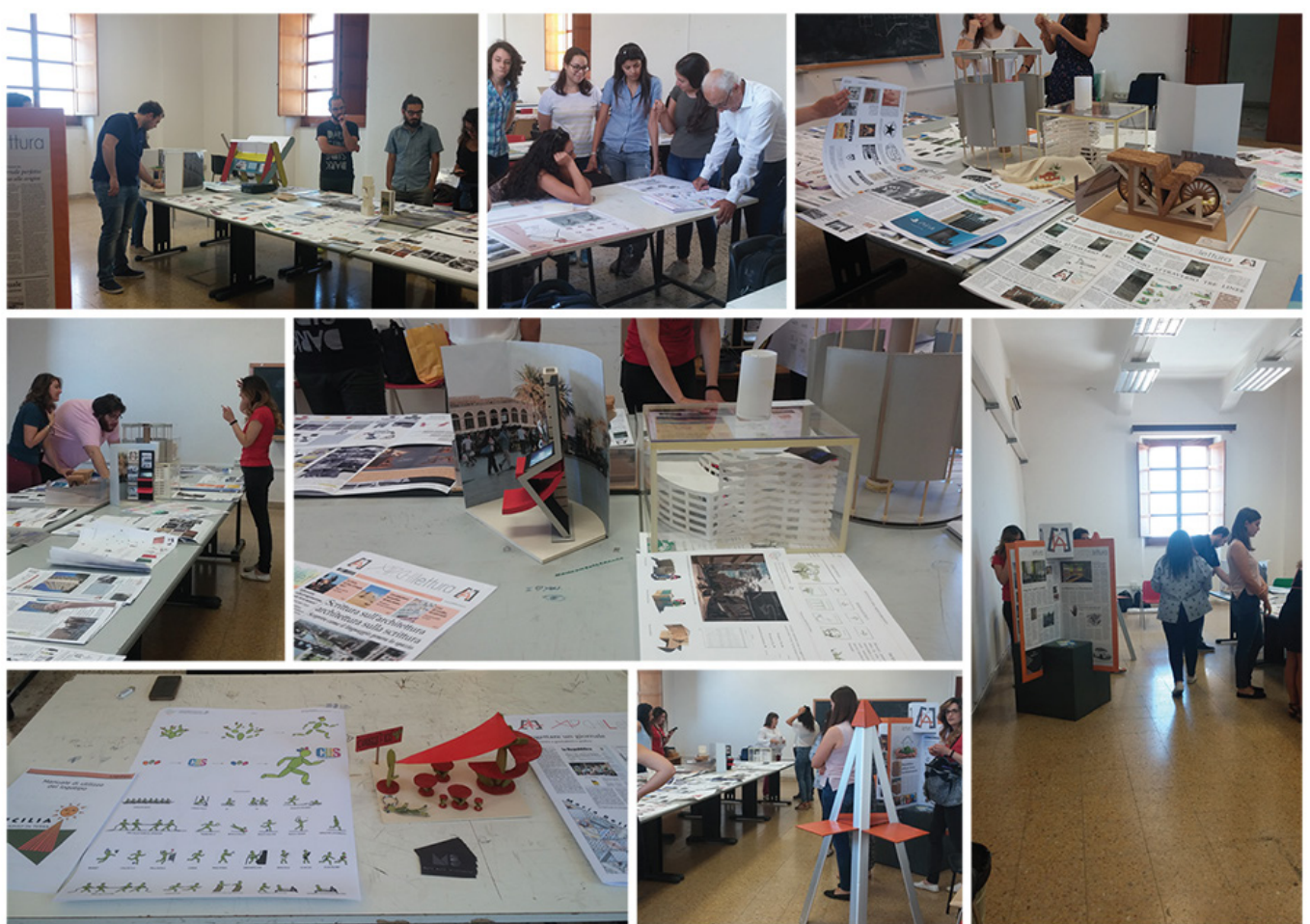
which shines all year round. Folklore, too, was taken into consideration with its traditional symbols and objects. Many were able to represent all these specific features in just one symbol (fig. 4).

Geometric analysis and the choice of shapes and colours formed the basis of discussion. The logo font was also considered crucial for the perfect harmony of the design and, above all, it should have delivered the intended message not affecting the symbol itself. The symbol had to arouse people's interest and curiosity. Last, the usage guidelines had to ensure its setting in different backgrounds such as the production of gadgets, a holiday brochure or even the creation of a website or of a mobile app (fig. 5).

The teaching activity had such positive results that the team decided to hold a contest internal to the institution setting up a commission of experts and graphic designers who, after an accurate analysis of the projects, awarded a prize to the most original, iconic and applicable logo. (E.P.).

\section{The newspaper architecture}

Archilettura is the name of the newspaper that a group of about ten students edited from 2016 to 2018 for the Newspaper Graphics Department within the course of Graphics and digital image processing.

Architecture and reading were fused in a neologism coined almost for fun but revolving into a unique experience of practice and theory.

The main objective was to provide the basic training for a future job in publishing (newspapers could have considerable advantages from innovation in design and contents and could overcome the crisis they're facing at the moment) [Harrower, Elman 20I3].

A completely fulfilled objective, as shown by the project results.

However, the experience revealed something more and unexpected: all the elements had a multiplier effect in the final results.

Interconnections generated new relations. From the teaching point of view, a dialectical relation between the teacher of the course and the journalist in charge of that section. From
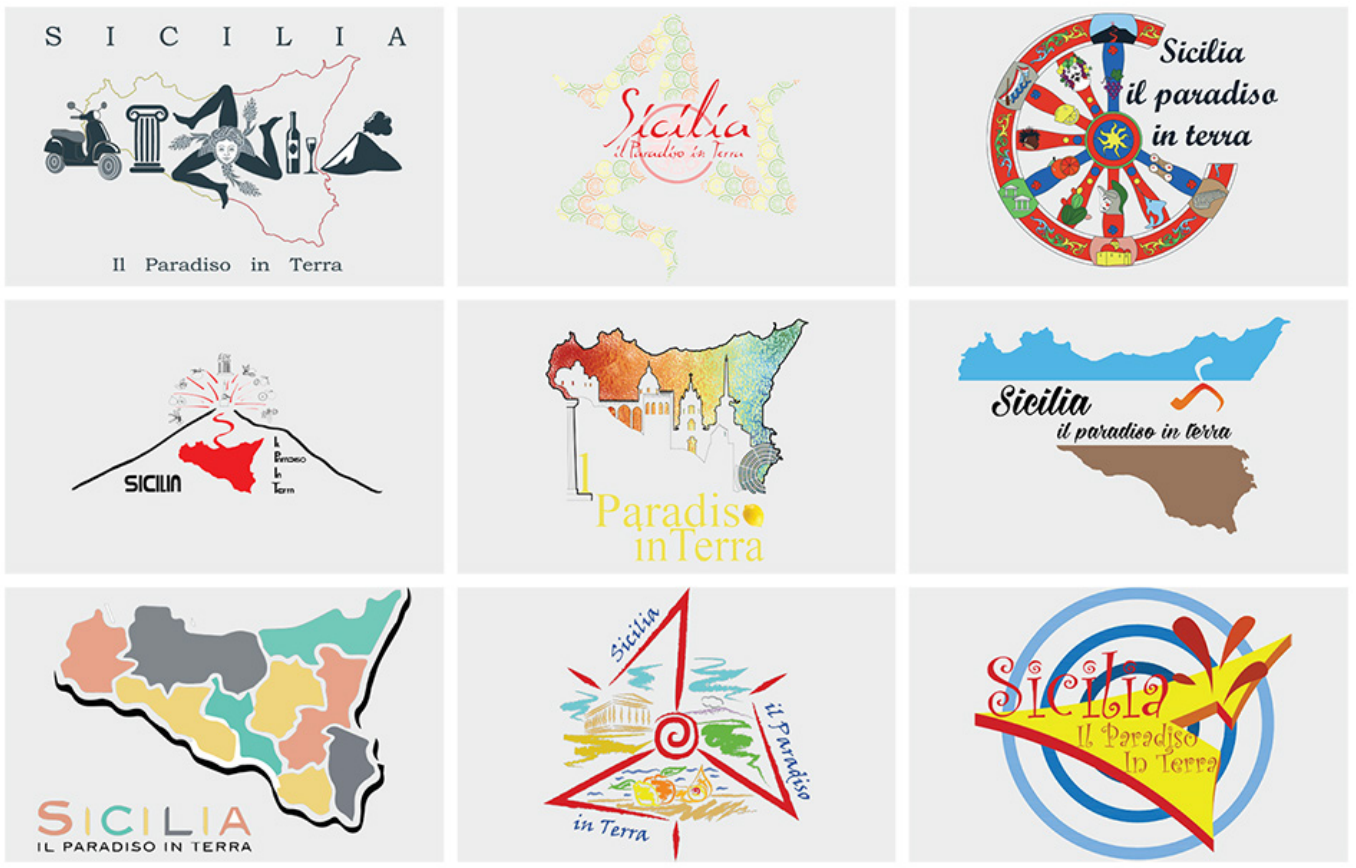
the learning point of view, the relation between the different tasks to be performed: each mini-newspaper was not only designed by the students but with articles and titles written by themselves.

They wrote news and comments under strict revision of syntax and contents because an article needs its own architecture. Thus, the task went beyond mere graphics (fig. 6).

But what has an architect to do with journalism? Writing represented a further effort requested by technical reasons: a newspaper designer should perfectly know what type of article he is going to publish. Not only dimension but also configuration and arrangement of space must be related to the type of topic he is going to deal with [Samara 20 17; Garcia 2002]. Students, then, could gain full knowledge about something he was the author of. Here the combinations of the different tasks became a multiplier of ideas.

There were benefits to the specific knowledge of the architect, in particular in the field of journalism. It had an effect similar to the process of association of ideas by which new intuition and original connections arise.

Writing gradually provided feedback on drawing, modifying and enriching it during all the project phases. In other words, students created very functional and attractive texts -beautiful, let's say- maybe because they were their authors.

Advertisement produced the same results. In the course of the second academic year, each student was given the task of developing an advertisement for his/her hypothetical professional office in relation with the layout of the newspaper, keeping them quite distinct from each other. An unusual task, indeed, since advertisement and news are ambiguously mixed together-sometimes advertisement may look like news- sometimes they cohabit, though separated, in bordering areas often in conflicts.
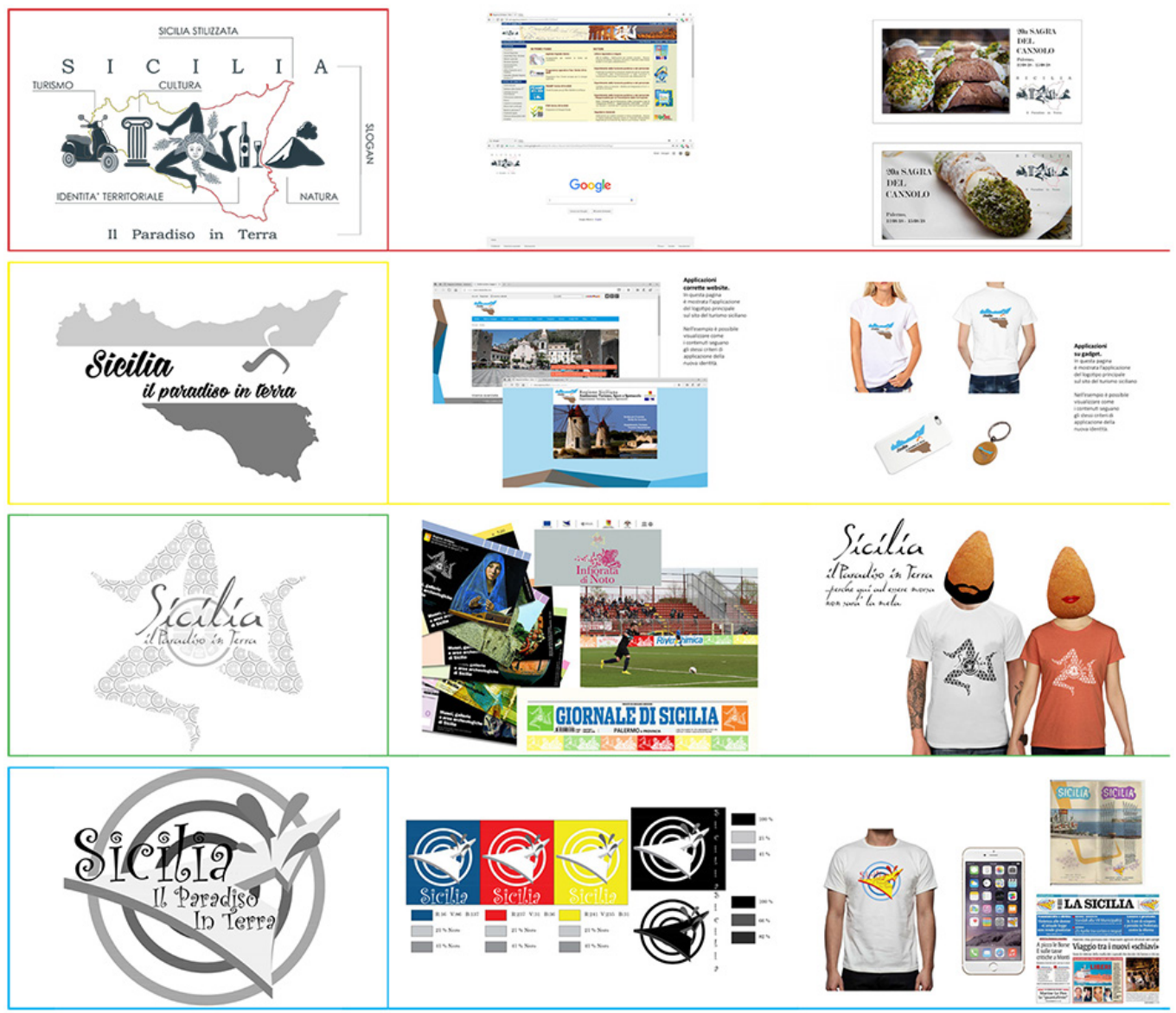
On the contrary, students were stimulated to organically combine aspects and contents of each subject area developing new potentially profitable products.

This task, too, generated attractive alternative models (fig. 7).

In conclusion, journalism and marketing became a real intellectual 'game' for these young students of architecture: an addition to horizontal extension right beside the compulsory vertical study of their specific syllabus. However, 'gamification' increases engagement and participation, especially when horizontal knowledge and vertical competence are the common thread connecting different skills. There is an extraordinary example. Leonardo da Vinci, whose areas of interest were unlimited, and though his being curious about everything was the reason why some of his works were left unfinished and others preparatory drawings were never painted, epitomized a spirit of scientific inquiry and inventiveness far ahead of his own time.

Actually, we really don't know if among the students of the Infographics group there was some sort of genius. However, that 'game' activated different connections in the learning circuit - teacher, journalist, newspaper, architecture, writing, marketing, vertical, horizontal. Beyond any doubt, the final product was arguably better than many real newspapers in many ways. (C.A.).

\section{Conclusions}

The adopted methodology brought about new teaching scenarios and supported learning in a variety of unusual contexts and subject areas. Students acquired new skills related to their future profession such as integration of exploratory approaches to learning (graphics and writing). Also, entering the contest promoted by the Region strengthened their creativity (newspaper infographics) and retention.

Indeed, the multidisciplinary methodology was greeted with enthusiasm and engaged the learners attending the course of study from 2016 to 2018, in a productive learning experience where the connections and exchanges between the two subject areas increased motivation and generated an unusual trend in architecture studies.

Fig. 6. Archilettura: the newspaper created by the students of Architecture (graphic elaboration by the students of Graphics and digital image processing. AY 2016-2017 and 2017 2018).
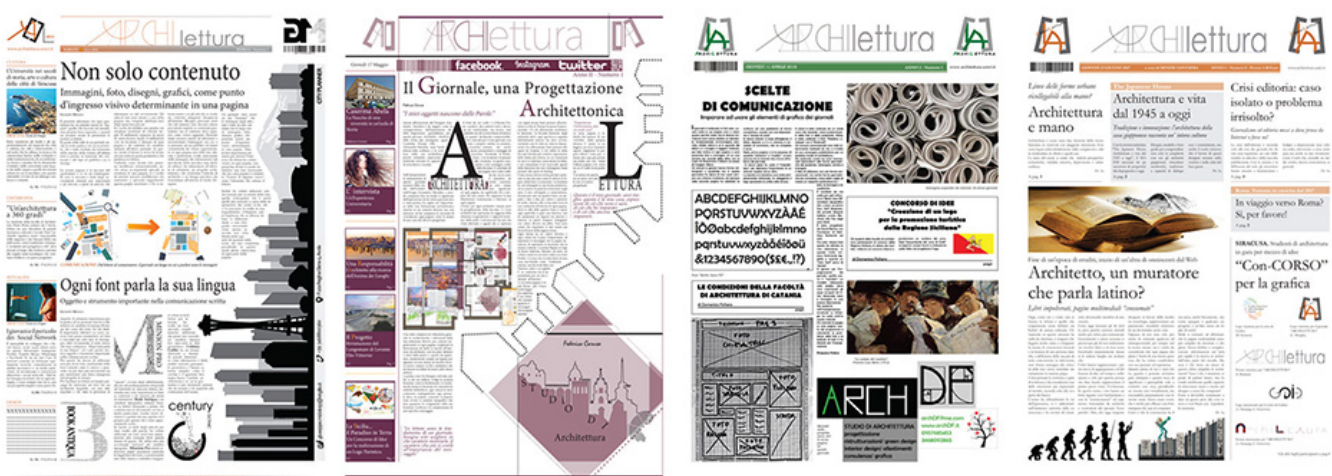
Fig. 7. Journalism and advertising: examples of graphic design (graphic elaboration by Paolo Florio).

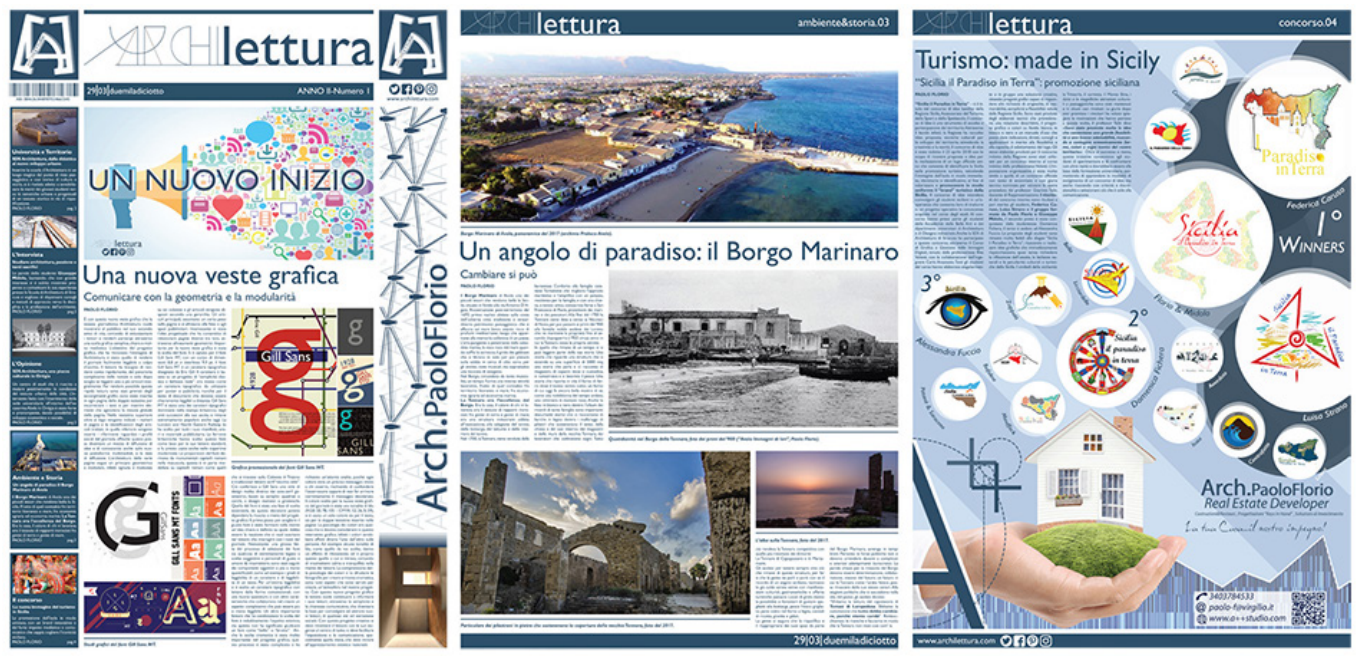

\section{References}

Garcia Mario (2002). Pure Design79 simple solutions for magazines, books, newspapers, and websites. St. Petersburg, Florida: Miller Media.

HarrowerTim, Elman Julie M. (20 I3). The Newspaper Designer's Handbook. New York: McGraw-Hill Education.

Mulè Paolina (a cura di). (20 I 8). Didattica generale e didattica disciplinare tra epistemologie e linee programmatiche di intervento. Lecce: Pensa MultiMedia Editore.

Munari Bruno (1981). Da cosa nasce cosa. Bari-Roma: Editori Laterza.

Munari Bruno (1968). Design e comunicazione visiva. Bari-Roma: Editori Laterza.

Samara Timothy (2017). Making and Breaking the Grid. Rockport: Rockport Publishers.

Valenti Rita (2009). I luoghi del disegno tra rappresentazione e concepimento dell'idea. In Voyantes, 2, pp. 30-35.

Authors

Carlo Anastasio, Quotidiano La Sicilia, carlo.anastasio21@gmail.com

Emanuela Paternò, Università degli Studi di Catania, patermanu@hotmail.it

Rita Valenti, Università degli Studi di Catania, r.valenti@unict.it

To cite this chapter Anastasio Carlo Paternò Emanuela Valenti Rita (2020). Connessioni per una didattica multidisciplinare: pensiero e espressività della comunicazione/Connections for a multidisciplinary teaching approach: thought and expressiveness of communication. In Arena A Arena M. Brandolino R.G. Colistra D. Ginex G. Mediati D. Nucifora S. Raffa P. (a cura di). Connettere. Un disegno per annodare e tessere. Atti del $42^{\circ}$ Convegno Internazionale dei Docenti delle Discipline della Rappresentazione/Connecting. Drawing for weaving relationships. Proceedings of the 42 th International Conference of Representation Disciplines Teachers. Milano: FrancoAngeli, pp. 31 -46. 